\title{
IMMIGRATION AND IDENTITY IN L'ALBERO DEI DESTINI SOSPESI
}

\section{LUCIANA D'ARCANGELI (Flinders University)}

\begin{abstract}
Sommario
L'albero dei destini sospesi (1997) del regista algerino Rachid Benhadj, da anni immigrato in Italia, è il primo film italiano a mostrare una relazione interrazziale tra una donna italiana ed un uomo nordafricano. I due giovani protagonisti partono per un viaggio in cui scopriranno i propri pregiudizi, paure e sentimenti ma anche le reciproche culture. In Italia sarà Maria a far da guida a Samir ed in Marocco i ruoli si invertiranno in modo da lasciare ad ambedue i protagonisti il tempo di accettare l'altro, e di apporre dei cambiamenti alla propria identità ed auto-categorizzazione. II regista fornisce un esempio positivo di convivenza ed integrazione fortemente apprezzato nelle scuole, se non dal grande pubblico, che si inserisce allinterno del progetto RAI Un altro paese nei miei occhi di Marco Bellocchio, particolarmente importante per l'Italia ora paese di immigrazione che necessita una nuova identità "creola".
\end{abstract}

L'albero dei destini sospesi (or The Tree of Suspended Destinies, 1997) by the Algerian émigré director Rachid Benhadj offers a perspective on the meeting of different cultures via an intimate description of the encounter between two disparate people: Samir, a young Moroccan man who has just arrived in Italy in search of a better life, and Maria, a young Italian woman with a troubled existence. The two meet by chance and what started as a short hitch-hiking trip becomes a long journey that eventually takes them to 
Morocco; their happiness is eventually marred by the pregnancy she keeps secret. In what is the first Italian funded film to represent an interracial relationship between an Italian woman and a North-African man, the culture-crossed lovers' feelings and fears that intersperse their process of acculturation ultimately result in changes to their self-categorisation and identity. L'albero dei destini sospesi succeeds in representing a positive model of cultural cross-fertilisation and the film is proving to have a long 'shelf-life' in Italian schools where it is still shown and can be found on migration syllabuses and bibliographies online. However, the film's public life was not so fortunate. ${ }^{1}$

The film was funded by RAI - the Italian national television network and by the director Marco Bellocchio as part of the project Un altro paese nei miei occhi (Another country in my eyes), which explored the phenomenon of immigration through film. Marco Bellocchio, Stefano Rulli and Sandro Petraglia, on the occasion of the $15^{\text {th }}$ International Young Cinema Festival held in Turin in 2008, explained:

We decided to give life to this project [...] because we believe in a rather basic principle: Peaceful coexistence, solidarity, dialogue among peoples, in human beings' ability to go forwards together in spite of a difference in skin colour, culture, history and religion. We do not believe that racial hatred is an innate instinct in mankind rather that mankind is born sociable, good and just. It is only at a second stage that we are taught to hate. It is for this reason that we are committed to participate in the creation of stories that tell of

1 The film could be freely streamed via internet for a number of years on http://www. raiclicktv.it/raiclick/pc/website/0,4388,5-734-734-CTY15-CID8171-0-0-0---1-1-ABB0,00.html until the raiclicktv was closed down. 
dramatic realities and which, at the same time, reinvent them in order to do good service to truth - because we believe in the 'political' power of the imagination. The better the films, the more they will allow people to rediscover and regenerate a feeling that the majority of them lose when growing up: the instinct to love without prejudice. ${ }^{2}$

Four films in total were produced, the other three were: Torino Boys by the Manetti brothers, L'appartamento by Francesca Pirani (who was also Bellocchio's assistant) and Di cielo in cielo by Roberto Diannarelli. Rachid Benhadj was the only African born director involved in the project and the only one ever to obtain funds usually reserved for Italian directors. ${ }^{3}$ Benhadj recalls:

It was interesting to work on this project. Then I realised that there had been a lack of maturity regarding the issue; a great deal of money had been invested in the project, and then my film was shown at 10.30 p.m. and the others in the middle of the night. [...] It is a serious question; on the one hand there is the will to talk about an issue, on the other the conditions to do so are not really there. ${ }^{4}$

2 Held on 21-29 November 2008, http://www.torinofilmfest.org/history.php?action=section\&ed $=15 \& \mathrm{ID}=98 \&$ lang=ita, 26.1.09. All translations from Italian are mine.

3 These were given to him twice: Once for the film in question and once for his Il pane nudo (2005). In both instances the majority of people working on the film were Italian and part of the film was shot in Italy. See E. Povoledo, "Painful stories, told with a passion for life", International Herald Tribune, 12.9.2006, http://www.iht.com/articles/2006/08/24/opinion/ fmlede25.php, 26.1.2009.

R. Benhadj, in L. Sarra, "I percorsi meticci nel cinema di Mohamed Rachid Benhadj", 9.3.2004, http://www.disp.let.uniroma1.it/kuma/SEZIONI/cinema/kuma8-cinema-sarra.html: 3, 30.3.2004. 
Even though one may tend to agree with the film-maker, and certainly understand his point of view, it is accepted that in Italy most 'intellectual' programmes are aired after 10 p.m. The film's première was, in fact, reported to be on Raidue at 23.15 on July $8^{\text {th }}, 1999$, and was watched by an audience of 900 people. $^{5}$ This formed a notable contrast with his previous, more popular, films - Louss/Rose des sables (1992), Touchia. Cantique des pierres d'Alger (1995), Mirka (2003) - and seems to be due to the more exegetic nature that TV films have in Italy, and to which the director has succumbed.

L'albero dei destini sospesi certainly does not have the impact of Benhadj's first work Immigration - a documentary shot in 1976 which focuses on the living conditions of 3,000 North-African immigrants in a shanty town in Nice. Instead the author worked with a different narrative and genre, exploring not humanitarian problems but the topic of immigration via a love-story with an Italian national. The film has been labelled 'African' because Africa is Benhadj's birthplace, but it was made possible by Italian funds and it has a more 'European' take on the issue of immigration as the storyline itself is far removed from those of the many films that deal with the pain and hardship endured by immigrants sans papier. ${ }^{6}$ L'albero dei destini sospesi transcends the practical and legal issues of immigration as Samir, the male protagonist, is never shown to have problems with his papers or with subsistence, but it tackles the more evasive issues of self-categorisation and ethnic identity related to

5 A. Fittante, "Home Video e TV 1998-99: Tuttofilm", in Segnocinema 99, Sett.-Ott. 1999: 67.

6 Seven tragic films on this topic from Maghreb were presented in Milan at the Festival del Cinema Africano in March 2003. See A. Gallone, "Nostalgia del ritorno", in http://www.enel.it/it/ enel/magazine/golem/Puntata27/stampa.asp?id=1192\&num=27, 30.3.2004. 
immigration. At the start of the film, Samir is shown the ropes of his new employment as cleaner and cook in an apartment run by an organised group of legally employed immigrants, many from his own birthplace. They share the common dream of sending money home, where they will someday return. Their homeland, where they could not make a living, has been idealised by time and distance, a place where one is protected, a second 'uterus'. Even though they do not share the same nationality they all seem to share the same social identity of successfully working émigrés; nevertheless Samir has not developed this self fully because of the confusion generated by what he describes as a 'woman's job' when compared to the 'men's jobs' the others carry out daily on building sites. Furthermore, he cannot yet share their longing for the home country because he is still enveloped in the dream which impelled him to emigrate: the 'pull' factors that attracted him to Italy - satellite television, advertisements and returning migrants with tales of success and riches together with the 'push' factors of lack of work and prospects that had helped to feed his myth of the North and reinforced his wish to stay, integrate into Western society and find a better job. This is where his developing perspective clashes with that of his fellow immigrants.

From the opening scenes, Samir is shown actively trying to shape a new identity by learning Italian while doing his daily chores, and viewers are presented with Samir's visualisation of the first Unit of his Italian language course. This features Rossi, the male speaker - an individual from Calabria in the South of Italy which is compared to Africa so frequently that it is termed 'Calafrica' - who is talking to the female speaker Belle, an American woman, as they dance. The romantic mental image the audience is shown implies Samir's desire for integration and intimacy with another 
person and immersion in another culture. ${ }^{7}$ This also echoes the director's personal experience when he moved to Rome in 1995 to live with his Italian wife, Benhadj being, in his own words, "a foreigner in my own land, [i.e. Algeria.] But there is no ideal country. We create our country in our heads; it's where the people you love are". ${ }^{8}$ The first scene thus foreshadows the appearance of the co-protagonist Maria, and what eventually happens to the couple during the film. However, more importantly, the scene also triggers a parallel between Italian immigration from past - Rossi learning to integrate in America - and the present immigration of Africans into Italy and Samir's attempts to learn Italian. The two phenomena are linked by the narrative, which hints at a positive finale for both. However, the immediate results are far from positive as the protagonist's fixation with learning Italian is a cause of distance, arguments and mirth within his community of immigrants. Samir's voluntary cultural immersion into Italian is somehow perceived as a 'betrayal' of the other immigrants' social identity and even the smallest domestic mishap is blamed on the language course. Samir is told "you don't need Italian" and "the guy before you only knew two words: 'thank you' and 'asshole'!” The film's mise-en-scène implies where the director's sympathies lie, as the migrants live in barrack-like surroundings, a claustrophobic effect being achieved through the use of chiaroscuro effects. They work in a tunnel in an all-male, 'closed' environment while Samir is shown, in total contrast, either outside or in colourful surroundings such as shopping malls, inhabiting what are essentially 'open' spaces linked with the feminine.

7 Cfr. E.H. Erikson, Identity: Youth and Crisis, London, Faber \& Faber, 1968: 135.

8

E. Povoledo, "Painful stories, told with a passion for life", International Herald Tribune, 12.9.2006, http://www.iht.com/articles/2006/08/24/opinion/fmlede25.php, 26.1.2009. 
The absence of women is highly significant in the film, although the idea of integration into an alien society through sexual intimacy/marriage is introduced at the film's opening when the language learning/daydream sequence ends with the lines "you must feel lonely, so far from your country" and Rossi and Belle kissing. However, this sequence finds no correspondence in the immigrants' lives as is shown by the feast organised to celebrate the arrival of Yussef - the son of the 'chief' of the village from where the immigrants originate - an individual who acts as a go-between and travels to and from Africa with communications, money and goods. For the occasion special food is cooked, music is played, one of the men dresses as a woman in traditional costume and dances to the approval of the other men in an attempt to recreate a homecoming feast far from home. This occasion is not only symptomatic of a lack of connection with the receiving society, but it is also a sterile simulacrum of everything as it would be 'back home', lacking an authentic female presence. The important role that women have traditionally played in immigration is thus denied as no women, whether from the original or the receiving culture, are present. The role of women, particularly in Italian immigration, has essentially been twofold: Those who stay behind in Italy to maintain family unity and to incentivize the eventual return of the men, and those who emigrate and become a point of reference for other immigrants, perhaps by opening boarding-houses. By giving birth to children, the women also contribute to the integration, assimilation and settlement of immigrants within the receiving society. ${ }^{9}$ Not only have Samir's companions left their women and families in their homeland, but they have also chosen not to integrate into Italian society - a decision that leaves them in stagnant socio-cultural isolation.

9 P. Corti, L'emigrazione Roma, Editori Riuniti, 1999: 12-14. 
The socio-cultural limbo of the immigrants is further emphasized by the photographs that Yussef gives out to his countrymen. Women and children, with only a few elderly men in the background, hold up the prized gifts he has delivered. These photos form a sharp contrast with the immigration photography to be found in archives around the world, ${ }^{10}$ more orthodox immigration photography being based mainly on representations of the immigrants themselves. The images are usually either taken or commissioned by themselves, and are self-referential and invariably positive in outlook - implying success - or they are taken by official and professional sources from the host nation, and often endowed with negative connotations related to economic distress. Thus, in an inversion of established practices, Benhadj chooses to reinforce the idea that the men have no life away from home and family, and as such does not construct a representational system for them. They do not take any pictures of themselves in their new surroundings and only receive photos from home; instead of traditional, self-celebratory immigrant photographs, they send money and presents which imply that they are well and working hard. Therefore, the photographs in the film are mainly a means of family communication: the men's gifts or money have been received, and at home their families are happy and waiting for their return. These images function more as 'receipts' for goods sent - in case there was any doubt of them reaching their destination - and an alluring symbol of continued family and social unity to which the close knit community of males aspire to return. However, this notion of a 'return' again separates the immigrant group from

10 Photographs of Italian immigrants may be found, among other sources in: Archivio Centrale dello Stato, Rome; Archivio del Ministero degli Affari Esteri, Rome; Archivio Centro Studi Emigrazione, Rome; Istituto Luce, Rome; Centre for Migration Studies, New York; Museum of the City of New York, New York; Tamiment Library, New York; Library of Congress, Washington; National Archive, Washington. 
Samir who instead seizes the opportunity to talk to Yussef in the hope of securing another job in Italy, as he is entirely focused on staying.

Samir's attitude to integration eventually proves to be correct when his broken Italian is used to call an ambulance in the wake of a car accident that involves Yussef. His heart attack and subsequent death effectively offer Samir the chance of a lifetime to replace Yussuf in his postman/Santa role. This would allow him to prove himself trustworthy in the eyes of his peers, the role also helping him to redefine and confirm his masculinity and his identity, and even to fulfil his greatest aspirations by acquiring the key role once held by the son of the chief. Samir takes the car and heads towards Marseille, contravening the wishes of his peers who do not think he is up to the task. He is inspired by the possibility of a worthwhile way of life; however, his poor driving skills attract abuse from other drivers, his lack of knowledge of the country and its roads, and his negligible map-reading skills do not bode well. It is at this point that Samir's providential encounter with Maria takes place; she is undergoing a crisis in her social relations since she is pregnant, has just resigned from her dead-end job, and has ended her relationship with her boss and partner. Maria hitches a lift from Samir to get home, but it soon becomes clear that she needs to escape social pressures and to rebuild her life and identity.

At this point in the film the director juxtaposes the two protagonists' cultural and gender values in a sequence which will see the characters start their journey towards a new identity, and an understanding of each other and their reciprocal cultures. When Maria addresses him for the first time to ask for a lift, Samir is dumbfounded and cannot reply, being almost disempowered by his lack of Italian; furthermore, it is soon clear that he also lacks the necessary cultural and social skills to deal with a native. Maria, on the other hand, has to rebuild her life by starting to trust the opposite sex while at the same time confronting her fears of the 'other'. 
After accepting the ride, the distressed woman is forced to face her prejudices right away. In the claustrophobic and limited space of the car created with the use of insistent close-ups and camera zoom - Samir stares at his guest's beautiful legs which are clad in black laddered tights. The woman reacts self-consciously, trying to pull down her short skirt to cover herself. Maria is alarmed as Samir stops the car and rummages through the contents of the car's boot. The ominous soundtrack noise is disconcerting, and the woman locks herself in the car. As the camera lingers on some kitchen knives stashed in the back of the car, tension mounts, only to be dissipated shortly afterwards when Samir finds and offers a pair of tights to the frightened woman. The build-up brings to the fore the 'aversive racist' in Maria and the Western spectator, seeking to destroy the seemingly liberal façade of those who preach tolerance but are in fact not ready for close contact or interaction with other races. ${ }^{11}$ The emotional paradox of finding her 'hyperbolic sexual aggressor' offering a pair of tights deflates Maria's (and the Western viewer's) irrational, prejudiced preconceptions as in the aftermath of the episode she laughs at her own archetypal fears and gladly accepts the gift from Samir. Throughout the film the director is always careful to portray Samir as very respectful, even though he is obviously attracted to his counterpart. This helps to assuage the "pathological fear that considers every immigrant to be a potential rapist, a thesis that continually resurfaces emphatically in the Italian press with every rare incident of sexual violence or rape usually attributed to an immigrant. The cliché of the immigrant as a potential rapist is in reality a central theme of all immigration stories. It was used for Southern Italians immigrating internally

11 L. Young, Fear of the Dark. 'Race', Gender and Sexuality in the Cinema, London \& New York, Routledge, 1996: 25. Cfr. J. Kovel, White Racism: A psychohistory, London, Free Association Books, 1988. 
to the richer North as well as with Italians and Turks in Germany, and it is not surprising that it is reappearing today as foreign workers arrive in Italy". ${ }^{12}$

Sexual images and innuendo are present from the very beginning of the film: The two language units of Samir's Italian course with Rossi and Belle dancing or going to a hotel feature a superficially innocent dialogue, but a sexual relationship is implied. The camera repeatedly frames a large street poster outside Samir's kitchen window that depicts a semi-nude woman; Maria's first appearance in the film is as a model in advertisements screened in the mall where Samir does his shopping and it focuses on her lip-glossed mouth, etc. This subtle titillation suggests how the attraction of the host culture and language grips Samir and lures him away from his own origins, and also implies that he sees women as a mechanism to achieve social integration, this notion being the film's conceptual cornerstone. However, interracial sexual intercourse is not high on the director's agenda, Maria's pregnancy complicating any sexual discourse. The focus of the film-maker is on intimacy - in terms of the psychological description previously given - and as the two protagonists eradicate each other's loneliness and get to know each other both on personal and cultural terms, Samir's language skills improve, sexual attraction becomes less predatory and a new power balance is achieved between the protagonists. Yet all this is to come as in the film narrative their interaction briefly comes to an end when Samir takes Maria home. This separation turns out to be temporary as he realises the quandary he is in: alone with a carload of goods and money

12 S. Palidda, "Immigrazione e sessualità" in http://www.deriveapprodi.org/rivista/16/palidda 16.html, 30.3.2004. This is reinforced by the political use of information by the media - see http://ricerca.repubblica.it/repubblica/archivio/repubblica/2009/01/29/la-barbarie-dello-stupro-intv.html, 2.2.09. These episodes have occasionally occurred in recent times but are unfortunately reinforced by the very political use that the media make of this information. 
to deliver, not knowing which way to go to reach Marseille. He goes back for her and for the first time enters the home of an Italian, stepping into a world he does not know or understand and which will leave him perplexed on more than one occasion.

In Maria's flat the director uses mise-en-scène for characterization purposes, portraying the female protagonist in her just-out-of-the-shower attire. For the first and only time, Maria appears in her natural state with her fashion outfits, make-up, and wig removed. Her short brunette bob now sits on a dresser with other styles of wig and her closet holds a diverse arrangement of clothes, a smorgasbord of different identities to suit every occasion. They are indicative of a woman who is busy trying to please the men in her life, but who is not comfortable with any of the different roles that Western society expects her to play - and it is implied that viewers see only a few such roles during the film. Both her ex-partner and father continually place demands on her and unwittingly force her to leave - first to Sanremo then to Morocco. Maria thus becomes drawn to Samir because he makes no demands but, on the contrary, asks for much-needed help. Their relationship is born simply out of necessity; she needs to distance herself from her established Western life, he needs a cultural guide to reach Marseille. Maria's pregnancy spurs her to undergo both physical and psychological changes, and to want to be more focused on her identity. Samir's presence helps her to move away from her normal lifestyle, to build a trusting, intimate relationship with a man and to find her own self. The filmic representation of Maria depicts her as a 'host' that is psychologically dysfunctional but physically adapted to her surroundings while the 'guest' Samir is portrayed as the opposite.

Maria agrees to take Samir only part of the way, as far as Sanremo since she wishes to attend a friend's wedding. The journey is enlivened by a reversal of conventional, 'received' notions of interpersonal relations 
between individuals such as Samir and Maria - those of migrant/host and man/woman - in an incident whose resonances are totally alien to Samir's culture. Samir drives his precious vehicle and tries never to let it out of his sight, he nevertheless has to answer a call of nature. During a short absence two men try to steal his car but are scared off by Maria who wields a gun at them. She does not stop there, and when Samir returns in alarm, she points her gun at him, aims and 'shoots' him. It turns out to be only a replica and the young man is unharmed but unamused by this incident in which a Western female unexpectedly assumes an imposing and threatening position with regard to an African male. Needless to say, he is grateful to Maria for reacting to the robbers but his smile is visibly more nervous than hers; the scene serves as a reminder that the world outside Samir's social group and community is still unfamiliar, disorienting and potentially hostile, even - or especially - with a native friend by his side.

The growing relationship between the two protagonists is a story of rolereversals, power-shifts, acculturation and, ultimately, trust-building which includes overcoming prejudices, social differences and ignorance. The latter is, in fact, the most important of the three problems as stated by the director: "The eradication of ignorance changes lives [...] leaving people in ignorance is what divides us"13. Ignorance generates fear and Benhadj chooses to highlight three incidents using nightmarish, distorted hand-held camera shots and eerie effects on the soundtrack such as disembodied voices reciting prayers, the wailing of women and the tinkling of percussion. These sounds emerge for the first time when Samir follows Maria into the ruins of a Catholic church, looking for shelter from the heavy rain. He feels impelled to flee the place as soon as he sees the engraving of

13 R. Benhadj, in E. Povoledo, "Painful stories, told with a passion for life", International Herald Tribune, 12.9.2006, http://www.iht.com/articles/2006/08/24/opinion/fmlede25.php, 26.1.2009. 
a cross on the wall and chooses to wait for Maria in the car outside. The disturbing soundtrack surfaces again in Sanremo when, at Maria's friend's wedding reception, the waiters bring in a whole roast pig. Samir feels physically sick when the meat is sliced, served and eaten by the participants and has to leave the room. This aural effect is used for the last time when, once Maria has agreed to go with him to Morocco, he tries to kiss her. This time he stops, gathers his wits, disobeys his internal voices and kisses her thus breaking an ancestral taboo. Maria may be different from the women of his homeland, even alien, but he has grown to know her and his emotions towards her override his reservations. These contrasting encounters create great internal tensions within Samir and are reflected in Benhadj's filmmaking techniques. The film's occasionally nightmarish visuals and soundtrack recede when Samir appears to have accepted and understood the nature of the cultural differences that confront him, but they return whenever the protagonist unexpectedly finds himself out of his depth in socio-cultural terms. Nevertheless, it is interesting that the film-maker chooses to present the spectator with instances of the outsider's problematic acceptance of the 'other', that is the host-culture, in a reverse operation that immediately reveals to a Western audience how unfounded Samir's, and consequently their, fears of the 'other' are.

The couple's trip to Africa initiates a further reversal of roles, and places Maria in the disconcerting situation where she is totally disoriented and dependent on Samir, who becomes the 'host'. The new situation, however, allows her the freedom to discover Morocco and her new companion, and also find a greater psychological and physical equilibrium. She abandons her wigs in favour of her natural hair, and her uncomfortable mises are replaced with long flowing kaftans; these are key elements in a process during which Maria finds the determination to make the necessary changes that will, eventually, allow Samir into her life permanently. Significantly, 
the act of leaving her country to 'find herself' mirrors a tendency in African film exemplified by Ben Mabrouk al-Sama's 1982 film The Trace, where "by emigrating and fleeing abroad, women look for the opportunity to express their real identity which has been oppressed by claustrophobic family environments". ${ }^{14}$ The shift in interpersonal relations caused by Maria becoming the 'alien' allows Samir to relax in what are more familiar surroundings, since he no longer has to rely on Maria's advice and abilities. In terms of the viewer's oscillating alignment with the two protagonists, the director tries to maintain a difficult equilibrium: There are times when the narrative and the film's visuals accentuate Samir's or Maria's individual problems and ethnicity, and also key features of their respective homelands, but neither character prevails in the overall balance of the filmic narrative. The pair try to reach out, explain and introduce each other to different manifestations of their own cultures, and occasionally there is the emergence of common ground. Magic, for example, unexpectedly bridges the two cultures. Maria has frequently consulted her Tarot cards to 'decipher' the world around her and once she explains their function to Samir, he immediately presents Maria with a Maghreb cultural equivalent by taking her to a Moroccan woman who practices molibdomancy - or divination by molten lead, which involves interpreting the hissing noises given off by the metal as it is dropped into water, and also analysing its final form. The old woman senses the younger woman's discomfort and asks "Have you done something that is hounding you?" It is a thinly veiled reference to Maria's pregnancy and her unease with it. Another African cultural ritual also becomes imbued with personal significance for Maria, a tradition from which the film takes its name; the tree of suspended

14 L. Bouzid Discacciati, "The Image of Women in Algerian and Tunisian Cinema", July 2000, in http://www.library.cornell.edu/colldev/mideast/cinmwmn.htm, 26.1.2009. 
destinies. It is a small, secluded, leafless tree, adorned by ribbons and tinkling objects which represent the wishes of women unable to have children. Only when the objects fall off the tree will the women's wishes come true and they will become mothers. Earlier in the film Maria had made it clear to her partner that she wanted to keep the child, but she is unable to find the strength to share her secret with Samir as she fears that it may alienate his new found trust. Maria's destiny is thus 'suspended' in a way as, unknowingly, is Samir's.

The heat and her pregnancy eventually take their toll on Maria, and she falls unconscious. A doctor breaks the news of her pregnancy to Samir and this precipitates events as the young man is naturally upset. He settles Maria's hotel bill, buys her a plane ticket home and continues his journey alone. The attention of viewers is abruptly switched from what was arguably a 'feminine' sequence of the film - predicated on two cultures meeting and generating new understandings - to one that concentrates on Samir's fight against his demons - his love for a foreign, non-Muslim pregnant woman - and his subsequent immersion in his own culture as he reaches a Bedouin tent camp. Under the influence of drugs and drink, Samir falls into the white waters of a river in a sequence that is heavily symbolic. $\mathrm{He}$ is once again lost in his own emotions and must either 'sink' and repudiate his recent experiences or 'swim' and embrace the new culture and its personification in Maria. The viewer's familiarity with film genre and narrative might elicit the expectation that Samir will return for Maria, but an unexpected plot development sees Samir's resume his journey towards his village in order to fulfil the role of Mulud (or Christmas as he calls it). He brings clothes, money and gifts, only to find that it does not feel like a homecoming; although he has attained a degree of professional fulfilment, his life is still lacking something. Samir's distance from what was once 'his' world is portrayed by the camera's long frontal shots of the character 
in the foreground of the frame, while the village and its inhabitants are spatially distant and located in the background. He therefore starts to retrace his steps, but instead of encountering Maria again, he only finds a wad of banknotes and note explaining that she has returned his money so that he will not lose his new job as 'postman'. She says:

I didn't have the courage to tell you everything. I wanted to run away, but this time I can't run away... [...] Our destinies are suspended and the wind enjoys billowing them about. I am sure that it will have us meet again. I am waiting for you, Maria.

The filmmaker chooses only to imply the possibility of their reunion, opting for a circular narrative structure by returning to the imagery of Samir's Italian course from the film's beginning. The last sequence evokes the characters of Belle and Rossi, only this time Maria is wearing Belle's vintage dress and Samir is wearing what were once Rossi's shoes. They are dancing and kissing as the narrator's voiceover explains the notion of the grammar of love; in the previous unit the characters had learned to express themselves in the past tense but in this last unit they will learn to express what their hopes and future hold. Having stabilized their identities and gained maturity, it is implied that the protagonists can now progress to the next stage of their existential journey and create a family enriched by each other's cultures. The film's narrative points towards a new 'creolised' future, similar to that created by many Americans of Italian descent; the evolution of a whole social group within which individuals become less significant. 
Benhadj stated: "You have to put people in the centre, that's why I choose these characters", ${ }^{15}$ therefore works such as L'albero dei destini sospesi are unashamedly character driven, the director choosing to work on a micro scale with individuals as a means of articulating larger macro-scale issues in a tangible way. For Benhadj it is also imperative to maintain a global, political focus:

The conflicts in Afghanistan and Iraq, terrorism, and the events of September $11^{\text {th }}$ have triggered many situations. The East and other cultures have imposed themselves with violence in Europe, reaching into people's homes through television. I believe it is important to compare oneself with a reality that has changed, and try to foresee a peaceful encounter between cultures. ${ }^{16}$

The latter is true of L'albero dei destini sospesi, a film whose focus is on bridging cultures and whose narrative perspective implies disapproval towards immigrants who do not wish to integrate. In the film, there is no sign of terrorism and violence or even of the bureaucratic or racial problems encountered in his previous and more forceful documentaries shot in France about African immigrants and the Beurs - second or third generation immigrants from North Africa. The main narrative 'problem' requiring resolution in L'albero dei destini sospesi seems to centre on the individual's ability and determination to embrace new cultures; the issue of the host culture's willingness to accept immigrants - despite obvious references to

15 R. Benhadj, in E. Povoledo, "Painful stories, told with a passion for life", International Herald Tribune, 12.9.2006.

R. Benhadj, in L. Sarra, "I percorsi meticci nel cinema di Mohamed Rachid Benhadj", 9.3.2004, http://www.disp.let.uniroma1.it/kuma/SEZIONI/cinema/kuma8-cinema-sarra.html: 4, 26.1.2009. 
the mass migration of Italians to America in the opening and closing scenes - receives far less emphasis. With regard to his work, the director suggests: "In my films I try to reveal the vital issues of existence and to give voice to those who are excluded from society", ${ }^{17}$ but this is less true of this film than of the others in his filmography, where protagonists face extreme poverty, disability, rape, war and prison. The film is also highly didactic and it seems to express concerns that are 'Italianised' and not indicative of the director's own poetics. One wonders how much impact receiving Italian funding had on Rachid Benhadj's storytelling, and whether he might categorize L'albero dei destini sospesi as an Italian or an Algerian film. One would tentatively say Italian in terms of the film's ideological content and aesthetics, as it is not indicative of the tendency of African/black cinema to resist cultural assimilation and to break with conventional ways of representing reality. ${ }^{18}$

However, Benhadj' refers to the problems of immigrants in interviews. Although he praises Italy for having a 'big heart' and expresses his admiration for the work of volunteers who help immigrants in a host of ways, he also accuses the Italian State of being too bureaucratic ${ }^{19}$ and suggests that Italian culture is 'closed at all levels' with respect to African

17 L. Leonardi, "Rachid Benhadj: «Il mio cinema: arte che dà voce a chi non ce l'ha»" in Rivistaorizzonti, n.20, Sept.-Feb., 2003: 46-9. Cfr. R. Benhadj, in E. Povoledo, "Painful stories, told with a passion for life", International Herald Tribune, 12.9.2006, http://www.iht.com/ articles/2006/08/24/opinion/fmlede25.php, 26.1.2009.

18 K. Mercer, "Diaspora culture and the dialogic imagination: The aesthetics of Black independent film in Britain" in M.B. Cham \& C. Andrade-Watkins, (eds.) Blackframes: Critical perspectives on Black independent cinema, Cambridge, Massachusettes: Celebration of Black Cinema Inc. and MIT Press: 50-61. Cfr. J. Comolli, J. Narboni, "Cinema/Ideology/Criticism" in B. Nichols, (ed.) Movies and Methods, Berkeley: University of California Press, 1976: 23-30.

19 N. Battaglia, "Intervista a Rachid Benhadj", 2002, in http://www.csav.it/20002002/csvinforma/numero 6/intervista.html, 30.3.2004. 
culture, particularly in schools. ${ }^{20}$ It is ironic he should say this, because his film L'albero dei destini sospesi, as was mentioned earlier, has been and continues to be shown extensively in Italian schools to sensitise young people towards migration and to the benefits that can be reaped by cultural creolisation and changes to original cultural patterns. An awareness of the issues underlying the phenomenon of immigration is important in the light of the large number of immigrants that Italy has received in recent times, individuals who have compensated for the country's population decline and aided its economic development but who have found themselves embroiled in new social problems and ethnic conflicts. ${ }^{21}$ Benhadj himself, in a less critical statement, has recounted how

The Italian Ministry [for Culture] has been quite sensitive towards the more universal issues that [my new film] Il pane nudo (or El khoubz el hafi) takes into consideration. ${ }^{22}$ The funding means that there is a certain interest in promoting projects that deal with issues connected with diversity. ${ }^{23}$

Therefore there are small windows of opportunity for projects such as L'albero dei destini sospesi even though these may already be closing on

20 A. Boano, "Festival del cinema africano - Milano, 2001" in Reporter, 2001, http://www.cinemah.com/reporter/milanoafrica/2001/, 26.1.2009.

21 D. Sam, J.W. Berry, "Introduction" to their edited volume, The Cambridge handbook of acculturation psychology, Cambridge: Cambridge University Press, 2006: 2.

22 The film's narrative premise, taken from a book by Mohamed Choukri with the same name, is that young men from developing countries can either meddle with drugs, emigrate at their own risk or find in education and culture ways to save themselves.

23

R. Benhadj, in L. Sarra, "I percorsi meticci nel cinema di Mohamed Rachid Benhadj", 9.3.2004, http://www.disp.let.uniroma1.it/kuma/SEZIONI/cinema/kuma8-cinema-sarra.html: 4, 26.1.2009. 
account of the political and financial climate. Projects like Benhadj's film have a resonance not only for Italians and Westerners, but also for Africans and Arabs, displaying sensitivities that testify to a willingness to cross cultural boundaries. This is especially important for Italy, because its relatively new incoming migration phenomenon does not appear to be a short term issue; indeed it arguably carries the seeds of a new Italian identity.

\section{A short biography}

Rachid Mohamed Benhadj was born in Algiers in 1949 to a traditional Muslim family; as a youth he was attracted to painting, sculpture, architecture and also to cinema. He was offered a scholarship to study cinema in the ex-USSR but was deterred by the seven year duration of the project. He eventually left Africa to study in France where he obtained a degree in Architecture at the Ecole Supérieure des Arts Decoratives de Paris and then a diploma in filmmaking at the Ecole de Cinéma de Paris in 1975.

In 1976 he directed a documentary (Immigration) on the conditions of North-African immigrants in a shanty town in Nice. After this he worked for Algerian state television and shot films, shorts, series and documentaries for TV. He also contributed to write several screenplays, as well as shooting his first feature film Louss/Rose des sables (1989) which was screened at the Cannes Film Festival. The film won numerous awards in international film festivals all over the world: Houston, Rome, Carthage, Festroia and Montpellier.

In 1995 Rachid Benhadj moved to Rome, where he married an Italian woman, and where he has been living ever since, directing, teaching cinema, and painting. 


\section{Filmography}

Immigration (1976, documentary)

Les aggresseurs (1979, feature film tv)

N. 49 (1980, feature film tv)

Stationnement interdit (1981, feature film tv)

Le mirage (1983, short)

Le fusil (1983, short)

Mille et une naissance (1984, documentary)

Couleurs nostalgiques (1985, documentary)

La soie (1986, short)

Louss, wards al-rimal (1989, feature film)

Touchia. Cantique des pierres d'Alger (1993, feature film)

L'ultima cena (1995, documentary)

Cari Comboniani (1980, documentary)

L'albero dei destini sospesi (1997, feature film, co-produced by RAI)

Mirka (2000, feature film)

Il pane nudo/El khoubz el hafi (2005, feature film)

\section{Bibliography}

Audenino P. \& Corti P. $\quad 2000 \quad$ L'emigrazione italiana, Milan: Fenice, (1994).

AA.VV.

2004 "Anche in Italia un cinema del melting pot", Comunità Universitaria, Brescia, Centro Universitario Diocesiano, n. 9, aprile.

Bhabha, H.

1987 "Interrogating identity" in L. Appignanesi, (ed.) Identity: The real me, London: ICA, ICA Documents 6: 5-11. 
Barthes, R.

Barthes, R.

Barthes, R.

Battaglia, N.

Benhadj, R.

Boano, A.

Bouzid Discacciati, L.

Corti, $\mathrm{P}$

Comolli, J. \& Narboni, J.

Di Sapio, A.
1961 "Le message photographique", in Communications, 1. Also in Barthes, R., L'obvie et l'obtus Paris: Seuil 1982: 9-24.

1964 "Rhétorique de l'image", in Communications, 4: 40-51. Also in Barthes, R., L'obvie et l'obtus Paris: Seuil 1982: 25-42.

1981 Camera Lucida, New York: Hill \& Wang.

2002 "Intervista a Rachid Benhadj", in http://www.csav.it/2000-2002/csvinforma /numero 6/intervista.html.

2003 "Quelle varianti della lingua italiana", Nigrizia, Settembr: 69-70.

2001 "Festival del cinema africano - Milano, 2001" in Reporter, http://www.cinemah. com/reporter/milanoafrica/2001/.

2000 "The image of women in Algerian and Tunisian cinema", in http://www. library.cornell.edu/colldev/mideast/cinmw $\underline{\text { mn.htm, July. }}$

1999 L'emigrazione, Roma: Editori Riuniti.

1976 "Cinema/Ideology/Criticism" in Nichols, B., (ed.) Movies and Methods, Berkeley: University of California Press: 23-30.

1996 "Il cinema algerino tra passato e presente", in Sete di libertà, http://www.manitese.it/ cres/stru696/ setedili.htm. 
Erikson, E.H.

Fittante, A.

Gallone, A.

Gentile, D. \& Ortoleva, P.

Gibelli, A.

Hall, S.

Hall, S.

Kovel, J.

Leonardi, L.
1968 Identity: Youth and crisis, London: Faber \& Faber.

1999 "Home Video e TV 1998-99: Tuttofilm", in Segnocinema 99, Sett.-Ott.

2003 "Nostalgia del ritorno", in http://www. enel.it/it/enel/magazine/golem/Puntata27/s tampa.asp?id=1192\&num=27, March.

1986 "Album di gruppo", in C. Ottaviano and P. Ortoleva (eds), Sapere la strada. Percorsi e mestieri dei biellesi nel mondo, Milan: Electa-Fondazione Sella.

1989 “«Fatemi un po' sapere»: scrittura e fotografia nella corrispondenza degli emigrati liguri", in La via delle Americhe. L'emigrazione ligure tra evento e racconto Genoa: Sage editore.

1989 "Cultural identity and cinematic representation", in Third Scenario: Theory and politics of location, Framework, 36: 68-81.

1990 "Cultural identity and diaspora", in Rutherford, J., (ed.) Identity: Community, culture, difference, London: Lawrence \& Wishart: 222-37.

1998 White racism: A psychohistory, London: Free Association Books.

2003 "Rachid Benhadj: «Il mio cinema: arte che 
dà voce a chi non ce l'ha»", in Rivistaorizzonti, n.20, Sept.-Feb.: 46-9.

Martini, M. (ed.)

Mercer, K.

Miranda, A.

Ortoleva, P.

Palidda, S.

Povoledo, E.

Ramella, F.

Romero, F.
1996 Migrazioni: comunità e nazione, Memoria e ricerca, A. IV, n.8, December.

1988 "Diaspora culture and the dialogic imagination: The aesthetics of Black independent film in Britain", in Cham, M.B. and Andrade-Watkins, C., (eds.) Blackframes: Critical perspectives on Black independent cinema, Cambridge, Massachusettes: Celebration of Black Cinema Inc. and MIT Press: 50-61.

1997 Pendolari di ieri, pendolari di oggi, Torino: L'Harmatton.

1991 "Una fonte difficile. La fotografia e la storia dell'emigrazione", in Altreitalie, n.5, April.

- "Immigrazione e sessualità" in http://www.deriveapprodi.org/rivista/16/pa lidda16.html.

2006 "Painful stories, told with a passion for life", International Herald Tribune, 12.9.2006

1996 "Emigrazioni", in B. Bongiovanni and N. Tranfaglia (eds), Dizionario storico dell'Italia unita, Rome-Bari: Laterza.

1991 Emigrazione e integrazione europea (19451973), Rome: Edizioni Lavoro. 
Sam, D. \& Berry, J.W.

Sarra, L.

Signorelli, A.

Sontag, S.

Tomizzi, M.E.

Tosi, L.

Triolo, R.

Vecoli, R.

Young, L.
2006 "Introduction" to their edited volume The Cambridge handbook of acculturation psychology, Cambridge: Cambridge University Press: 1-7.

1994 "I percorsi meticci nel cinema di Mohamed Rachid Benhadj", 9.3.2004, http://www.disp.let.uniroma1.it/kuma/SEZ IONI/cinema/kuma8-cinema-sarra.html.

1994 "Movimenti di popolazione e trasformazioni culturali", in F. Barbagallo (ed) Storia dell'Italia repubblicana, Turin: Einaudi.

1978 On photography, London: Allen Lane.

1999 Le grandi correnti migratorie del '900, Turin: Paravia.

1989 "Nota sulla fotografia", in L.Tosi (ed), $\mathrm{La}$ terra delle promesse. Immagini e documenti dell'emigrazione umbra all'estero, Perugia: Electa-Editori Umbri Associati.

2002 "Le commedie di integrazione e il cinema nelle società complesse", in http://www.sncci.it/default.asp?content=\%2 F34\%2F50\%2F1390\%2Fceter\%2Easp\%3F.

1990 "The invention of ethnicity. Una lettura Americana", in Altreitalie, n.3, April.

1996 Fear of the dark. 'Race', gender and sexuality in the cinema, London \& New York: Routledge. 
Zancarini-Fournel, M.

Zocaro, E.

Zonca, V.
1991 "Usage de la photographie et immigration: de l'identification à l'intégration, le photographe de Ponts-Saint-Etienne, 19171959", in La Trace, n.5, October.

2000 "Dall'emigrazione all'immigrazione. Lo schermo della speranza", in http:// www.cinegiornalisti.it/cinegiorasp/cinema g/2000/2_2000/emigrazione.htm.

2003 "Ciak di pace dall'Africa", in http://www.solidea.org/ONG/ICEI/Docum entazione/Archivio/0305-FestCinema Africano.pdf, May. 